\title{
A dependência entre a administração pública e a Constituição: uma via de mão dupla
}

Kaline Ferreira Davi*

\section{Introdução}

Desde o final do século passado, a dogmática brasileira sofreu um impacto que alguns chamam de pós-positivismo ou principialismo. Caracteriza-se pelo esforço de se ultrapassar o legalismo estrito, que rejeitou o jusnaturalismo e as categorias metafísicas. É um movimento de oposição ao positivismo normativista que dá ensejo à normatividade dos princípios; à definição de sua relação com valores e regras; à reabilitação da argumentação jurídica; à formação de uma nova hermenêutica constitucional; e, principalmente, ao desenvolvimento de uma teoria dos direitos fundamentais edificada sobre o fundamento da dignidade humana. ${ }^{1}$

Diante dessa transformação de eixo central, todo o ordenamento jurídico e todos os ramos do direito passaram a ter como parâmetro de legitimidade a Constituição. A esse movimento, Luís Roberto Barroso, Paulo Ricardo Schier e Clèmer-

\footnotetext{
* Mestra em direito público pela Universidade Federal da Bahia, advogada da União, representante da Escola da AGU na Bahia, professora convidada da especialização em direito do estado da UFBA.

1 "A Constituição passa a ser, assim, não apenas um sistema em si - com sua ordem, unidade e harmonia - mas também um modo de olhar e interpretar todos os demais ramos do Direito. Este fenômeno, identificado por alguns autores como filtragem constitucional, consiste em que toda a ordem jurídica deve ser lida e apreendida sob a lente da Constituição, de modo a realizar os valores nela consagrados. A constitucionalização do direito infraconstitucional não identifica apenas a inclusão na lei maior de normas próprias de outros domínios, mas, sobretudo, a reinterpretação de seus institutos sob uma ótica constitucional" (Barroso, 2003b:328-391).
} 
son Merlin Clève ${ }^{2}$ chamam de "filtragem constitucional", e Tércio Sampaio Ferraz ${ }^{3}$ chama de "força neutralizadora da Constituição". É o fenômeno por meio do qual todos os institutos do direito são vistos sob a ótica das normas constitucionais, e o direito administrativo, por sua vez, não poderia ficar à margem desse fenômeno. ${ }^{4}$

Essa mudança de eixo do direito, que passou a ter como substância e limite a Constituição, ocorreu com o fim da II Guerra Mundial, acompanhada da decadência da teoria tradicionalista, centrada na lei, fato que está diretamente associado à derrocada do fascismo na Itália e do nazismo na Alemanha, quando regimes se apoiaram na legalidade para cometer todas as barbáries de que o mundo teve notícia. Isto pôde ser sentido no Tribunal de Nuremberg, onde os acusados não se mostravam cruéis assassinos, mas apenas burocratas que alegavam ter cumprido a lei. ${ }^{5}$

Com o surgimento desse novo ideal de justiça implementado pelos valores constitucionais, o ambiente humano tornou-se muito mais seguro, haja vista que o direito protegeu-se contra as criações arbitrárias e egoísticas das subjetividades transitórias, estabelecendo garantias rígidas de um mínimo de valores assegurados, que não poderiam ser modificados ao sabor das opções e conveniências políticas.

\section{Entendendo o fenômeno neoconstitucional}

Luís Roberto Barroso ${ }^{6}$ sintetiza o pensamento sobre o neoconstitucionalismo a partir de alguns marcos que resultaram nesse profundo fenômeno de constitucionalização do direito: (i) como marco histórico, aponta a formação do Estado constitucional de direito; (ii) como marco filosófico, o pós-positivismo mostra a

\footnotetext{
${ }^{2}$ Cf. Clève (1993); e Schier (1999).

3 "A noção dogmática e ideológica de legitimidade permite uma compreensão operacional da Constituição, para se obter uma congruência entre seus diversos planos de atuação. Essa noção faz com que no agir constitucional e no agir conforme a Constituição, normas valham em procedimentos que equivalem a suposições do consenso de todos. Isto é possível porque, num sentido global, legitimidade é tomada como uma espécie de valoração neutralizadora, ou seja, um ponto de vista avaliativo que tem por efeito básico a neutralização, entendendo-se por neutralização não a eliminação, mas a possibilidade de fazer com que outras possibilidades não sejam levadas em conta, ou seja, não sejam tomadas como relevantes" (Ferraz, 1989:19).

4 "A Constituição é o instrumento por meio do qual os sistemas democráticos e de direitos fundamentais se institucionalizam no âmbito do Estado. O processo por meio do qual tais sistemas espraiam seus efeitos conformadores por toda a ordem jurídico-política, condicionando e influenciando os seus diversos institutos e estruturas, tem sido chamado de constitucionalização do direito ou neoconstitucionalismo" (Binenbojm, 2006:86).

${ }^{5}$ Barroso, Luís Roberto. Neoconstitucionalismo e constitucionalização do direito, o triunfo tardio do direito constitucional no Brasil. Jusnavigandi. Disponível em: <http://jus2.uol.com.br/doutrina/imprimir. asp?id=7547>. Acesso em: 19 set. 2006.
}

${ }^{6}$ Ibid, p. 8. 
centralidade dos direitos fundamentais e a reaproximação entre direito e ética; e (iii) como marco teórico, indica mudanças que incluem a força normativa da Constituição, a expansão da jurisdição constitucional e o desenvolvimento de uma nova dogmática da interpretação constitucional.

Podemos depreender do excerto supra que as modificações referidas pelo autor culminam no efeito máximo desse processo, que é justamente a disseminação dos valores constitucionais ${ }^{7}$ por todo o sistema, com força normativa, cogente, relegando a lei a uma posição de absoluta subordinação, passível, inclusive, de invalidação e retirada do ordenamento jurídico, caso viole a norma fundamental.

É oportuno enfatizar que constitucionalizar o direito não é o mesmo que inserir na Constituição normas de vários ramos distintos. O processo de constitucionalização refere-se a uma mudança de ponto de vista em relação ao objeto que se analisa; é a reinterpretação de institutos sob uma nova ótica, o que impõe a conclusão de que toda aplicação do direito envolve aplicação da Constituição, seja de forma direta ou, principalmente, de forma indireta (Barroso, 2006:12).

Ana Paula de Barcellos (2005:83-103) ordenou as principais características do neoconstitucionalismo, dividindo em dois blocos pertinentes a elementos de natureza diferente: um congregando os elementos formais e o outro englobando os elementos materiais. Em se tratando do aspecto formal, o neoconstitucionalismo baseia-se em três premissas: a normatividade da Constituição, ${ }^{8}$ a superioridade da Constituição ${ }^{9}$ e a centralidade da Constituição no sistema jurídico, o que implica na interpretação de todos os ramos do direito a partir dela e por meio dela. ${ }^{10}$

Entendemos, acerca dessa sistematização, que da normatividade da Constituição exsurge a obrigação jurídica de cumprimento dos mandamentos constitucionais, principalmente por parte do poder público em relação aos direitos fundamentais; da superioridade da Constituição decorre o limite para o legislador, tanto ordinário - legislativo - como extraordinário - executivo.

\footnotetext{
${ }^{7}$ Sobre o tema, Diogo de Figueiredo Moreira Neto escreve: "Por derradeiro, mas não sem menor importância, a mutação alcança as Constituições, convocadas a desempenhar um novo papel, qual seja o de oferecer a superior referência positiva de princípios fundamentais, aos quais se vão acrescentando princípios gerais até setoriais, para vários ramos do direito, tais como, e.g., os atinentes à Constituição Econômica, à Constituição Cidadã, à Constituição Social, a de um protoestatuto para o Servidor Público e de um outro, para a magistratura, e até de um, para os serviços públicos, que atraem a si a referência aplicativa do direito e possibilitam a sua direta influência, rompendo a metodologia geométrica da pirâmide normativa kelseniana. Enfim, está encetada a marcha, aparentemente irreversível, da constitucionalização do direito, desvendando ricos desdobramentos aplicativos da Lei Maior, a serem garimpados e desenvolvidos: um fenômeno sobre o qual muito já se tem escrito ultimamente sob a designação de neoconstitucionalismo" (Moreira Neto, 2006:235).

${ }^{8}$ Para aprofundamento do tema, vide Hesse (1991).

${ }^{9}$ Cf. Barroso, 2003a:161-174.

${ }^{10}$ Esse assunto, que se confunde com o efeito central da constitucionalização do direito administrativo, será tratado com profundidade mais adiante.
} 
Em se tratando especificamente da centralidade da Constituição decorre a grande inovação trazida pelo neoconstitucionalismo, que é a leitura do direito sob o filtro constitucional, capaz de aproximar o direito de valores dantes dele apartados, como a moral e a ética.

Tratando do aspecto material, a autora enuncia dois elementos caracterizadores do neoconstitucionalismo: a incorporação explícita de valores e opções políticas nos textos constitucionais, com ênfase para a promoção dos direitos fundamentais e da dignidade humana; e, ainda, a inclusão dentro do sistema constitucional de conflitos entre as opções políticas e filosóficas.

A citada autora adverte para o fato de que nesses elementos materiais caracterizadores do neoconstitucionalismo reside seu maior desafio, pois, inserindo no texto constitucional valores e opções políticas, essas matérias foram erigidas à categoria de norma, não afetas originalmente ao direito. Dotadas de coercitividade, elas passaram de valores morais e políticos à condição de norma jurídica, vinculativa e obrigatória, não integrando mais a discricionariedade da política. ${ }^{11}$

Para nós, essa irradiação constitucional vinculante sobre todo o ordenamento jurídico é o que justifica chamar de "neo" - novo - o constitucionalismo já existente desde a implantação do Estado liberal. Essa é a novidade trazida pela Constituição Federal brasileira de 1988, que além de não conter meros conselhos, mas sim impositivos jurídicos, ${ }^{12}$ também constituiu importante marco evolutivo na juridicização do político e na reaproximação de valores éticos e morais com o direito, considerado em toda a sua plenitude.

Essa possibilidade de filtragem das normas do ordenamento jurídico, de capacidade legitimadora das normas positivas, bem como a força neutralizadora da

\footnotetext{
11 “As Constituições contemporâneas, sobretudo após a Segunda Guerra Mundial, introduziram de forma explícita em seus textos elementos normativos diretamente vinculados a valores - associados, em particular, à dignidade e aos direitos fundamentais - ou a opções políticas, gerais (com a redução das desigualdades sociais) e específicas (com a prestação, pelo Estado, e serviços de educação). A introdução desses elementos pode ser compreendida no contexto de uma reação mais ampla a regimes políticos que, ao longo do século XX, substituíram os ideais iluministas de liberdade e igualdade pela barbárie pura e simples, como ocorreu com o nazismo e com o fascismo. Mesmo onde não se chegou tão longe, regimes autoritários, opressão política e violação reiterada dos direitos fundamentais foram as marcas de muitos regimes políticos ao longo do século passado.

Com a superação desses regimes, diversos países decidiram introduzir em seus textos constitucionais elementos relacionados a valores e a opções políticas fundamentais, na esperança de que eles formassem um consenso mínimo a ser observado pelas maiorias. Essa esperança era reforçada - e continua a ser - pelo fato de tais elementos gozarem do status de norma jurídica dotada de superioridade hierárquica sobre as demais iniciativas do Poder Público. Por esse mecanismo, então, o consenso mínimo a que se acaba de referir passa a estar fora da discricionariedade da política ordinária, de tal modo que qualquer grupo político deve estar a ele vinculado" (Barcellos, 2005:85).

12 "A força normativa da Constituição não se resume apenas na adaptação de uma realidade. A constituição jurídica tem como objetivo converter-se ela mesma em força ativa, ou seja, ela não deve ser apenas um repositório de forças, mas ela mesma deve representar uma força propulsora para o desenvolvimento. Para isso ela tem que contar com a consciência dos responsáveis pela ordem constitucional, que terão que fazer presente não só a vontade do poder, mas também a vontade da Constituição" (Hesse, 1991:56).
} 
Constituição decorre de característica própria de nosso sistema jurídico, que é um sistema normativo de regras, princípios e diretrizes políticas, similar ao modelo português, conforme lição de Canotilho (2003:1159-1187). De acordo com a tradicional doutrina juspositivista, os princípios tinham uma função subsidiária e supletiva na ordem jurídica, o que pode ser globalmente constatado ainda hoje pelo teor do art. 4ํ da Lei de Introdução ao Código Civil Brasileiro. ${ }^{13}$ Já no direito constitucional, especificamente, a marca deixada pela doutrina positivista foi a redução no valor dos princípios, considerados como "normas constitucionais não autoaplicáveis, desvestidas de valor jurídico". ${ }^{14}$

Atualmente, as discussões doutrinárias acerca da normatividade da Constituição passaram a versar, principalmente, sobre esses elementos normativos que ora integram o sistema jurídico e não se confundem com as regras. Os esforços se concentram na distinção entre esses outros elementos normativos e as regras; sobre a aplicação desses mesmos elementos pelos operadores do direito; e sobre as técnicas de harmonização de conflitos entre essas novas normas. ${ }^{15}$

Interessa-nos em especial, na doutrina de Ronald Dworkin (2002:36), a ideia de que o sistema jurídico, além de conter regras e princípios, também está integrado por um terceiro elemento que não se confunde nem com as regras, nem com os princípios. São as políticas, que o autor assim designa:

tipo de padrão que estabelece um objetivo a ser alcançado, em geral uma melhoria em algum aspecto econômico, político ou social da comunidade (ainda que certos objetivos sejam negativos pelo fato de estipularem que algum estado atual deve ser protegido contra mudanças adversas) (...).

Essa noção contrapõe-se ao que o Dworkin (2002:36) denomina "princípio":

um padrão que deve ser observado, não porque vá promover ou assegurar uma situação econômica, política ou social considerada desejável, mas porque é uma exigência de justiça ou equidade ou alguma outra dimensão da moralidade.

Constata Eros Grau (2002:94-95) que a categoria política de Dworkin identifica-se com os princípios constitucionais impositivos descritos por Canotilho, ${ }^{16} \mathrm{bem}$

\footnotetext{
${ }^{13}$ Art. 4ํำ da LICC: “Quando a lei for omissa, o juiz decidirá o caso de acordo com a analogia, os costumes e os princípios gerais do direito".

${ }^{14}$ Vide Sarmento, 2006:60-61.

${ }^{15}$ Para aprofundamento do tema, vide Canotilho, 2003; Dworkin, 2002; Alexy, 2002; e Grau, 2002.

16 "Nos princípios constitucionais impositivos subsumem-se todos os princípios que, sobretudo no âmbito da Constituição dirigente, impõem aos órgãos do Estado, sobretudo ao legislador, a realização de fins e a execução de tarefas. São, portanto, princípios dinâmicos, prospectivamente orientados. Estes princípios designam-se, muitas vezes, por preceitos definidores de fins do Estado, princípios diretivos fundamentais, ou normas programáticas definidoras de fins ou tarefas"' (Canotilho, 1995:173).
} 
como com o que ele denomina norma-objetivo, constituindo-se todas essas categorias em impositivos aos órgãos do Estado, enunciadores dos fins das políticas públicas. E é justamente por assumir essa função de cunho teleológico que toma para si a importante tarefa de determinar o processo de interpretação do direito (Grau, 2002:196-197).

Verificamos que, seja na teoria dworkiana, na qual se encontram diferenciadas as políticas dos princípios, seja na teoria de Eros Grau, ${ }^{17}$ que considera as diretrizes como normas-objetivos, seja na teoria de Canotilho (2003:1159-1187), na qual a política está abrangida pelos princípios impositivos, é comum a ideia de que as diretrizes traçadas para a implementação das políticas integram o direito e têm força cogente, portanto, constituem impositivo aos entes públicos ou privados que prestam atividades de natureza pública.

Observe-se que listamos anteriormente, com base na lição de Ana Paula de Barcellos (2005:84), os elementos materiais caracterizadores do neoconstitucionalismo, citando a incorporação explícita de valores e opções políticas no texto constitucional, o que, associado aos elementos formais caracterizadores do mesmo fenômeno - superioridade, centralidade e normatividade da Constituição - aponta claramente para o maior desafio neoconstitucionalista: a criação de uma teoria que consiga impregnar de eficácia jurídica esses padrões - princípios e políticas - que não são da mesma espécie que as regras, mas estão dotados de força normativa.

Oportuno frisar, entretanto, que as argumentações jurídicas de princípios tendem a estabelecer um direito individual, enquanto as argumentações jurídicas de políticas visam a estabelecer uma meta, uma finalidade coletiva (Comparato, 1997: 44). Além disso, complementa Comparato, a política, como programa de ação, não pode ser considerada nem como norma, nem como ato jurídico, distinguindo-se completamente dos elementos jurídicos sobre os quais os juristas desenvolveram suas reflexões ao longo do tempo. ${ }^{18}$

Tecidas essas considerações básicas para o entendimento genérico do fenômeno neoconstitucional, sem pretensão de ter esgotado o assunto, passaremos a demonstrar a incidência do fenômeno neoconstitucional sobre o direito administrativo e suas principais consequências, tema central deste artigo.

\footnotetext{
${ }^{17}$ Eros Grau critica a diferenciação formulada por Dworkin (2002) entre princípios e política, utilizando como argumento suas próprias afirmações: "A distinção pode ruir se interpretarmos um princípio como a expressão de objetivo social (isto é, o objetivo de uma sociedade na qual nenhum homem beneficia-se de seu próprio delito) ou interpretarmos uma política como expressando um princípio (isto é, o princípio de que o objetivo que a contém é meritório) ou, ainda, se adotarmos a tese utilitarista segundo a qual os princípios de justiça são declarações disfarçadas de objetivos (assegurar a maior felicidade para o maior número). Em alguns contextos a distinção tem usos que se perdem, quando ela desmorona dessa maneira" (Grau, 2002:198-199).

${ }^{18}$ Ao afirmar que a política não se confunde com ato, nem com norma, Comparato (1997:44) está se referindo não à diretriz prevista constitucionalmente como elemento normativo abstrato e genérico, mas à forma de concretização e implementação dessas políticas.
} 


\section{A constitucionalização do direito administrativo como forma de superação de uma defasagem teórica}

Muitos doutrinadores nacionais que teorizam sobre direito administrativo, prevalecendo-se de ideias que embasam o regime jurídico-administrativo, principalmente na supremacia do interesse público sobre o interesse privado, justificam a vulneração de "direitos fundamentais e de seu regime jurídico-constitucional" (Schier, 2005:114-218), o que demonstra a contramão do direito administrativo brasileiro em direção ao processo de constitucionalização.

No mesmo sentido, o processo de constitucionalização do direito administrativo ainda está pendente de concretização, porque o instrumental teórico em que se funda esse direito está fora do contexto histórico, social e político do país (Justen Filho, 2005a:36). Para Justen Filho, o direito administrativo ainda convive e reflete as necessidades de um século atrás, quando sua fundamentação teórica e filosófica se relacionava com a disputa entre Duguit e Hauriou ${ }^{19}$ - sobre o que deveria integrar o conteúdo de serviço público - e a organização administrativa estruturava-se nos moldes rígidos da hierarquia militar napoleônica.

Diante da desagradável constatação desse atraso no desenvolvimento do direto administrativo em relação à realidade sociopolítica, Marçal Justen Filho chega a imputar ao direito administrativo, cujo ritmo de evolução não acompanha o do direito constitucional, a dificuldade encontrada por esse ramo do direito em efetivar os valores que consagra. Afirma esse autor (2005a:13) que dotar um país de uma constituição não é o bastante para se realizar os valores desejados, pois “(...) a transformação concreta da realidade social e sua adequação ao modelo constitucional dependem primordialmente do desenvolvimento de atividades administrativas efetivas".

Adotamos sem restrições o ponto de vista do autor citado, esclarecendo que a afirmação transcrita supra em nada diminui ou altera a supremacia da Constituição e sua força normativa, ao contrário, permite concretizar os ideais constitucionalistas que têm como elementos caracterizadores formais tanto a supremacia da Constituição quanto sua força normativa. A ideia é não permitir que essa supremacia e normatividade constitucionais resumam-se a meros elementos de discurso, o que somente ocorrerá com o auxílio do direito administrativo.

No mesmo sentido, afirma Caio Tácito (2006:27-90) que o direito administrativo e o direito constitucional completam-se, pois as constituições se tornarão

\footnotetext{
19 Para Marçal Justen Filho (2005a:18) a disputa travada entre esses pensadores franceses no início do século XX não poderia ter se deslocado nunca para a nossa realidade, pois o cerne das discussões incidia sobre o critério de definição da competência da jurisdição administrativa, não adotada no Brasil, que contempla jurisdição única.
} 
inúteis repositórios de conselhos sem o socorro do direito administrativo, "(...) que fará do sonho a realidade, da norma programática a efetividade da prestação administrativa, como duas faces que se completam na concretização dos ideais de justiça e igualdade social".

Na tentativa de explicar a origem desse descompasso entre o direito administrativo e o direito constitucional, Gustavo Binenbojm ${ }^{20}$ narra a história do direito administrativo numa versão pouco conhecida, partindo de sua gênese e passando por toda a sucessão de impulsos contraditórios que marcaram a evolução desse direito, que, para ele, é produto da tensão dialética entre a "(...) lógica da autoridade e a lógica da liberdade".

Nessa narrativa, Gustavo Binenbojm (2006:14-15) demonstra que é falsa a noção de que o direito administrativo nasceu submetido à vontade do legislador. Segundo o autor, sua origem é pretoriana, uma vez que foi obra do conselho de Estado francês a formulação de princípios gerais e novas regras jurídicas derrogatórias do direito civil aplicado aos casos envolvendo a administração pública. Daí deduzir que a criação de um direito especial para a administração pública não decorreu da vontade geral, mas sim de decisão autovinculativa do próprio Executivo.

O resultado da tensão entre a lógica da liberdade e a lógica da autoridade, na maioria das vezes não se mostra tão revolucionário ou garantístico como parece, ao contrário, mostra-se muito mais inclinado a preservar o que já existia. As mudanças são muito mais superficiais e cautelosas, próprias daqueles que, sofrendo do mal de um paradoxo como manter/romper, decidem imprimir apenas algumas mudanças ao sabor e ritmo de suas conveniências políticas, não desejam limites impostos pelo direito, nem tampouco aplicadores imparciais e independentes (Binenbojm, 2006:14-15).

Demonstrada a ausência de contemporaneidade do direito administrativo com o cenário econômico, social, político e também com o direito constitucional, apresenta-se a constitucionalização do direito administrativo como a solução para seu "déficit teórico", o que ocorrerá mediante a "adoção do sistema de direitos fundamentais e do sistema democrático como vetores axiológicos" ${ }^{21}$

\footnotetext{
${ }^{20}$ A versão doutrinária corrente de que o direito administrativo nasceu com o cunho "garantístico" de limitar o poder à lei, superando a estrutura política do antigo regime, é completamente desacreditada por Gustavo Binenbojm, que assim opõe sua crítica: "A associação da gênese do direito administrativo ao advento do Estado de direito e do princípio da separação de poderes na França pós-revolucionária caracteriza erro histórico e reprodução acrítica de um discurso de embotamento da realidade repetido por sucessivas gerações, constituindo aquilo que Paulo Otero denominou ilusão garantística da gênese. $\mathrm{O}$ surgimento do direito administrativo, e de suas categorias jurídicas peculiares (supremacia de interesse público, prerrogativas da Administração, discricionariedade, insindicabilidade do mérito administrativo, dentre outras), representou antes uma forma de reprodução e sobrevivência das práticas administrativas do Antigo Regime que a sua superação. A juridicidade embrionária da Administração Pública não logrou subordiná-lo ao direito; ao revés, serviu-lhe apenas de revestimento e aparato retórico para a sua perpetuação fora da esfera de controle dos cidadãos" (Binenbojm, 2006:11).

${ }^{21}$ Binenbojm (2006:16). Essa é a solução apontada pelo autor citado, que lista os principais déficits teóricos do direito administrativo: (i) o princípio da supremacia do interesse público sobre o privado; (ii) a
} 
Assim posto, encontramo-nos inseridos no seguinte contexto: a Constituição e o direito constitucional precisam do direito administrativo como instrumento de realização das transformações sociais; em contrapartida, o direito administrativo precisa da assimilação dos valores constitucionais para poder desenvolver seu instrumental teórico e se mostrar capaz de guiar a administração pública - considerada em sua acepção mais ampla - na concretização dos programas constitucionais.

Acreditamos que o direito administrativo, ao se submeter à força constitucional neutralizadora ou passar pelo filtro constitucional, adotará a Constituição como cerne da vinculação administrativa à juridicidade, o que será responsável pelas demais mudanças que consistem, principalmente, ${ }^{22}$ na "aproximação entre a administração e os cidadãos" e na redução da extensão e importância de termos como "legalidade", "interesse público", "discricionariedade" e "mérito administrativo", que terão que ser redimensionados em níveis constitucional e democrático. ${ }^{23}$

\section{Aproximação entre a administração e os cidadãos mediante a processualidade adequada}

Com a crise da democracia representativa (Baptista, 2003:121-122), que por questões práticas constitui-se no modelo democrático dominante, a administração vem sofrendo o influxo do descrédito social no tocante a tudo o que diz respeito ao poder político e seus agentes. Assim, foi imperiosa a busca por outras práticas de legitimação que não apenas aquelas relativas às pessoas que decidem - governantes - , mas, principalmente, à forma como elas deverão governar - escolhas políticas (Moreira Neto, 2006:58). É fruto de um progresso histórico ainda em lento desenvolvimento - pelo menos nos países em processo de democratização - a diminuição da distância entre poder político, sociedade e indivíduo, pois os modelos políticos antigos - até meados do século XX - fundamentavam-se na coerção como forma de impor comportamentos e assegurar uma convergência social (Moreira Neto, 2006:61). Logo se reconheceu, entretanto, que nenhuma força coercitiva é capaz de assegurar íntegra a convergência social por longo período, sendo

\footnotetext{
legalidade administrativa como vinculação positiva à lei, traduzida numa suposta submissão total do agir administrativo à vontade previamente manifestada do Poder Legislativo; (iii) a intangibilidade do mérito administrativo consistente na incontrolabilidade das escolhas discricionárias pela administração; (iv) ideia de um Poder Executivo unitário baseado na subordinação hierárquica.

${ }^{22}$ Para Diogo de Figueiredo Moreira Neto (2006:236-237), os focos de atraso do direito administrativo formam a seguinte lista, sem pretensão de exaustividade: 1o a imperatividade sem limites; 20 a intangibilidade dos atos políticos; $3^{\circ}$ a insindicabilidade da discricionariedade administrativa; $4^{\circ}$ a exclusão do administrado das decisões, inclusive por deficiência processual; $5^{\circ}$ persistência mítica do conceito de razões de Estado e de supremacia do interesse público.

${ }^{23}$ Cf. Bucci, 2006a:36; Binenbojm, 2006:25; e Justen Filho, 2005a:14.
} 
imprescindível a obtenção da adesão popular por outros meios, o que nos remete ao pensamento de Jürgen Habermas (2003:189), para quem só haverá legitimidade quando as decisões políticas se originarem de um procedimento democrático que permita a participação de todos aqueles que sofrerem seus efeitos.

Interliga-se, portanto, indissociavelmente, a participação popular a um processo racional de comunicação que garanta a intervenção igualitária de todos, sob pena de não podermos considerar o consenso obtido como expressão da democracia substancial, festejada nas constituições modernas e que não fazem distinções conceituais sobre o que é o povo. Nesse particular, vale transcrever o pensamento de Friederich Müller (2003:57-58):

Já que não se pode ter o autogoverno, na prática quase inexequível, pretende-se ter ao menos a autocodificação das prescrições vigentes com base na livre competição entre opiniões e interesses, com alternativas manuseáveis e possibilidades eficazes de sancionamento político. Todas as formas de decisão representativa arredam (nehmen aus dem spiel) a imediatidade (Ummittelbarkeit). Não há nenhuma razão democrática para despedir-se simultaneamente de um possível conceito mais abrangente de povo: do da totalidade dos atingidos pelas normas: one man one vote. Tudo o que se afasta disso necessita de especial fundamentação em um Estado que se justifica como "demo" cracia.

Acatamos o pensamento sobre a necessidade imperiosa da participação popular no exercício dos poderes políticos, e sobremaneira na gestão pública, o que legitimará a atividade administrativa independente da legitimação política de seus agentes. Contudo, somente será concretizada essa participação efetiva pela processualização adequada ${ }^{24}$ que garanta oportunidade de serem ouvidos todos os setores da sociedade que, de alguma forma, sofrerem os efeitos dessas escolhas e práticas administrativas.

Sobre essa participação na administração, Agostín Gordillo (2003) enaltece as multiplicações das previsões de técnicas consultivas e de gestão participativa nos ordenamentos jurídicos, o que, para ele, garante não apenas maior democratização, mas também uma satisfação mais efetiva das aspirações sociais. Para esse autor, a administração pública como instrumento dessa satisfação deverá tornar-se uma das primeiras áreas de ação a institucionalizar a participação direta do povo.

O autor não só menciona a legitimação, mas enfatiza, ao lado dela, a eficiência como outra importante justificativa para a adoção do modelo de participação po-

${ }^{24}$ Cf. Justen Filho, 2005a. 
pular. Essa posição coincide com a de Patrícia Baptista (2003:133), segundo a qual é pela participação que o administrador terá acesso a uma gama maior de informações, obtendo "(...) visão mais completa dos fatos e das questões relacionadas ao objeto da decisão", o que contribuirá para melhorar a qualidade das decisões administrativas.

Nessa mesma vertente é o posicionamento de Marcos Augusto Perez (2006:134192), para quem a legitimidade e a eficiência são finalidades que se alimentam reciprocamente, havendo uma relação direta entre o aumento da legitimidade e o aumento da eficiência na atuação administrativa e vice-versa.

O que podemos extrair desses argumentos, de forma muito evidente, é que há uma estreita ligação da participação do povo na tomada de decisões com a qualidade das decisões adotadas. O que não deve surpreender, haja vista ser de alcance do senso comum que ninguém dirige melhor seus interesses do que os próprios interessados, principalmente sendo eles os principais afetados.

Com apoio em Marçal Justen Filho (2005b:39-41), alertamos que a democratização não é tarefa da lei; é uma escolha de governo. Não é imposta pela Constituição, mas sim criada pela própria sociedade. Essas afirmações nos levam a uma conclusão: que a democratização das práticas administrativas concretizadas pela participação popular nos processos decisórios é de responsabilidade do governo e da sociedade.

Em relação ao governo, não haverá gratuito incentivo a uma prática que legitima o poder de forma impessoal e genérica, desmistificando a figura do "salvador da pátria". O governo não é simpático à intervenção popular em assuntos políticos, considerados ainda hoje pela doutrina pátria como atos insindicáveis pelo Judiciário.

O governo somente acatará e incentivará a participação popular efetiva quando ela for cogente, quando dela depender a validade da decisão adotada. Enquanto as audiências públicas e demais instrumentos de participação forem previstos apenas como "plano abstrato e exclusivamente teórico" 25 não poderemos falar em previsão de verdadeira participação popular, mas apenas em disfarce para neutralizar o argumento da ausência de legitimidade.

Vale ilustrar, citando a Lei no 9.472/97, ${ }^{26}$ instituidora da Anatel, que prevê em seu art. 42 a submissão das minutas de atos normativos à consulta pública, que seria um importante instrumento de participação social não fosse pelo forte caráter formalista, demonstrado ao prever a divulgação no Diário Oficial da União, cuja

\footnotetext{
${ }^{25}$ Expressão cunhada por Baptista, 2003:139.

${ }^{26}$ Lei no 9.472/97, art. 42: "As minutas de atos normativos serão submetidas à consulta pública, formalizada por publicação no Diário Oficial da União, devendo as críticas e sugestões merecer exame e permanecer à disposição do público na Biblioteca".
} 
publicação não alcança parcela expressiva da população. Além disso, a consulta visa apenas críticas e sugestões dos cidadãos, que, segundo o dispositivo, "merecerão exame", não constando em nenhuma parte do diploma legal citado no que consiste esse exame e de que forma ele será procedido. ${ }^{27}$

A despeito de todas as vantagens que enaltecemos em relação à participação da sociedade na atividade administrativa, não são poucas as críticas lançadas a esse modelo, nem inexistentes os riscos de distorção do papel desempenhado pela participação, o que passaremos a analisar.

O primeiro argumento levantado seria a perda do caráter técnico inerente à administração pública, que passaria a ser direcionada por cidadãos destituídos de conhecimentos específicos sobre questões administrativas complexas. Contrapomos a esse argumento o fato de que o cidadão não será chamado para discutir questões que envolvam áreas técnicas complexas, mas sim a relação custo/benefício da proposta administrativa, o que não requer profundo conhecimento em nenhuma especialidade. Qualquer indivíduo que gerencia suas finanças e tem consciência de suas necessidades prioritárias pode optar em relação ao que vale a pena ser feito ou não.

Cabe enfatizar, entretanto, que essa suposta dificuldade em tornar as discussões acessíveis ao público, por versarem sobre questões técnicas e complexas, segundo relata Marçal Justen Filho (2005b:39-41), não passa de uma manobra engendrada pela administração, que, no intuito de afastar uma interferência inconveniente, torna o diálogo impossível, diante da absoluta falta de compreensão acerca das propostas apresentadas. ${ }^{28}$

O segundo argumento contra a efetivação dos procedimentos participativos seria a lentidão e o encarecimento dos processos decisórios da administração pú-

\footnotetext{
${ }^{27}$ Nesse sentido, a crítica contundente e oportuna de Paulo Modesto: "Reivindica-se com veemência a superação dialética da democracia representativa pela democracia participativa, encarecedora da participação direta dos cidadãos na tomada das decisões coletivas. Infelizmente, neste tema como em outros, o entusiasmo da vontade frequentemente obscurece a clareza da razão. Diversas abordagens do tema têm incorrido em discursos retóricos, pouco ocupados com questões de um detalhamento mais sistemático e realista das formas de operacionalização da participação popular. Diante da dificuldade na objetivação do tema, parece urgente refletir exatamente sobre as formas básicas de participação e os instrumentos processuais que lhe podem servir de veículo de expressão, bem como sobre as condicionantes extralegais da participação cidadã, pois a participação popular tem sido entre nós sobretudo um discurso, não se traduzindo de modo constante e relevante em facticidade" (Modesto, Paulo. Participação popular na administração pública: mecanismos de controle. Jus Navigandi. Disponível em: <http://jus2.uol.com.br/doutrina/texto.asp?id=2586> Acesso em: 21 out. 2007).

28 "Por exemplo, no processo de regulamentação das agências reguladoras há a realização de audiências públicas, mas elas abordam temas tão complexos que nenhum cidadão se dispõe a participar. Somente haverá participação popular quando as discussões forem feitas de modo a permitir a compreensão sobre o conteúdo e a extensão das decisões. O que as pessoas entendem a propósito da concessão de rodovias? A grande maioria dos cidadãos não entende nem a questão técnica, nem jurídica, mas entende os aspectos econômicos, que é 'quanto eu vou pagar e qual é o benefício que terei'" (Justen Filho, 2005b:40).
} 
blica, o que comprometeria a eficiência administrativa. Redarguimos esse argumento com base na aferição da melhoria de qualidade das decisões administrativas com a consulta direta daqueles que, conhecendo os fatos de perto, podem prestar informações mais precisas sobre a matéria objeto da decisão.

Patrícia Baptista (2003:157) acrescenta que a participação na administração vale o custo da democracia que, envolvendo mais pessoas, implica em maior despesa operacional do que a decisão tomada por poucos ou por apenas um.

Por derradeiro, Marcos Augusto Perez (2006:173-175) apresenta como perigosa a abertura da administração à participação, pelos riscos da aproximação entre o governo e os movimentos sociais, o que pode conduzir à incorporação destes como um setor do Estado. Tal manobra lembra as práticas fascistas italianas e a história do populismo na América Latina e, realmente, é uma ameaça real à participação administrativa. Entendemos que a única forma de afastar o perigo da captura dos movimentos sociais pelo governo é a institucionalização da participação por meio da transparência e da racionalidade dos procedimentos e mediante a efetivação das formas existentes de controle: judiciais e políticas.

\section{Dimensão constitucional do princípio da legalidade}

Diante dessa premente necessidade de constitucionalização do direito administrativo, entra em crise um de seus pilares mais consistentes, que é a vinculação positiva à lei, como se a administração pudesse ser realmente apenas uma aplicadora mecanicista da regra legal. A erosão da lei formal e o desprestígio do legislador, somados ao surgimento do Estado providência, que criou para a administração pública uma série de atribuições novas, culminou com a derrocada do paradigma da estrita vinculação legal (Binenbojm, 2006:35).

Necessário, entretanto, fazermos uma breve análise da doutrina tradicional brasileira e da concepção por ela difundida no meio jurídico acerca da vinculação da administração à lei.

Para Hely Lopes Meirelles (2007:87), enquanto na administração particular é lícito fazer tudo o que a lei não proíbe, na administração pública só é permitido fazer o que a lei autoriza. Para Miguel Seabra Fagundes (1950:17), administrar era aplicar a lei de ofício. Para Jean Rivero (1981), a lei era o fundamento e a medida da administração.

Baseada nessa doutrina clássica foi construída a dogmática do direito administrativo brasileiro, que era adequado para um momento histórico, político e sociológico que não mais existe. Construímos um Estado democrático de direito dotado de uma constituição com força normativa e por isso não podemos admitir que seja imposta uma inversão na sistemática jurídica para privilegiar a norma 
infraconstitucional em detrimento da Constituição, com absoluta indiferença a sua superioridade.

Para Carmen Lúcia Antunes Rocha (2004:83-84), a atividade administrativa é o direito dinamizado. Nesse sentido, não se pode falar que ela se submete ao direito, mas sim que ela faz funcionar o direito posto pela norma, sendo apenas outra etapa desse processo de fazer o direito, a de concretização. A juridicidade é o liame que identifica o direito em sua estática (legislação) e em sua dinâmica (administração), conferindo harmonia e unidade à ação estatal.

Podemos concluir, a partir dessa relação direta estabelecida entre a atividade legislativa e a atividade administrativa, dois momentos distintos de elaboração do direito, que a mesma obediência devida pelo legislador à Constituição da República é devida pelo administrador público, cuja ação tem o mesmo caráter de primariedade que as outras ações estatais, legislação e jurisdição, não se subordinando a nenhuma delas. ${ }^{29}$ Por isso é que Carmen Lúcia Antunes Rocha (2004:84) justifica a necessidade de submissão da atividade administrativa à lei, já que as duas ostentam qualidade paritária: “(...) para se resgatar a juridicidade que, eventualmente, e por desmando e ruptura em determinado desempenho, se verifique tenha ocorrido".

Acreditamos, nesse caso, que a lei será parâmetro para a atividade administrativa retomar o curso da legitimidade, o que somente ocorrerá se a lei não tiver divorciada da materialidade da Justiça e da expressão dos valores fundamentais da sociedade, hoje positivados na Constituição. Portanto, é mediante a distinção entre legalidade e legitimidade, ${ }^{30}$ amadurecida no século XIX, principalmente a partir do segundo pós-guerra, considerando a "legalidade como exercício do poder e a legitimidade como qualidade do poder", que é formada a ideia de juridicidade administrativa, como reunião da forma (legalidade) e da substância (legitimidade) (Rocha, 2004:104-106).

Não é mais admissível no mundo contemporâneo a ingênua afirmação de que a lei como expressão da vontade geral já presume a legitimidade. ${ }^{31}$ Os exemplos

\footnotetext{
${ }^{29}$ Em sentido contrário, Geraldo Ataliba defende a superioridade da atividade legislativa: "Essa fenomenologia é universal e tem clara e objetiva explicação: a mais transcendental de todas as funções do Estado é a legislação. Tudo o mais é-lhe subordinado: todas as demais funções resolvem-se em obedecer à lei, dar cumprimento à lei. Por isso, Kelsen valoriza tanto o processo de criação do Direito como critério do estudo científico de suas manifestações" (Ataliba, 2007:68).

${ }^{30}$ Nesse sentido, Diogo de Figueiredo Moreira Neto (2006:52) argumenta: “Nem por outra razão, tenho marcado em meus escritos que entendo a legitimidade como um valor que se agrega à legalidade, pois se esta é a adequação da lei à vontade política formalmente manifestada, a legitimidade é a adequação da manifestação política formal à vontade geral, tal como o entendem grandes pensadores sociais contemporâneos do porte de Carl Schmitt, Niklas Luhmann e Jürgen Habermas".

${ }^{31}$ Ensina Eros Roberto Grau (2003:178): "Eis então a legalidade erigida em mito do liberalismo burguês, sob o qual repousa a afirmação, extraída à falaciosa leitura de Max Weber (1969), de que legalidade, enquanto legitimidade racional, foi e permanece sendo. A legalidade, destarte, enquanto noção que
} 
são fartos e atestam o sentido contrário dessa falsa noção, expondo a facilidade com que a lei formal foi utilizada como instrumento de dominação e como até hoje é objeto de um jogo político que na maioria das vezes não visa o interesse do povo. ${ }^{32}$

Assim, a legalidade administrativa não é rejeitada pelo direito administrativo, mas passa a ocupar uma posição secundária em relação à juridicidade administrativa, que prestigia os princípios e regras constitucionais como parâmetros de aferição da legitimidade das leis.

É nesse sentido que Gustavo Binenbojm (2006:143) adota a juridicidade administrativa em substituição à legalidade, que deixa de ser princípio altaneiro para se tornar princípio intrínseco a um conceito mais amplo - juridicidade - , o que acarreta modificações profundas na vinculação da atividade administrativa, que será, em regra:

(i) segundo a lei quando esta for constitucional (atividade secundum legem);

(ii) mas pode encontrar fundamento direto na Constituição, independente ou para além da lei (atividade praeter legem), ou, eventualmente; (iii) legitimar-se perante o direito, ainda que contra a lei, porém com fulcro numa ponderação da legalidade com outros princípios constitucionais (atividade contra legem, mas com fundamento numa otimizada aplicação da Constituição) [grifos do autor].

De acordo com a lição extraída do excerto supra, o autor admite a atuação administrativa até mesmo contra legem, desde que a lei se mostre inconstitucional e o princípio da legalidade ceda num juízo de ponderação com outros valores. ${ }^{33}$

A atividade administrativa contra legem, quando a lei se mostra inconstitucional, em nada fere a estabilidade ou segurança jurídica em favor dos cidadãos, configurando-se como consectário lógico de tudo o que acabamos de defender acerca da necessidade de ampliação do conceito de legalidade formal como parâmetro da atuação administrativa.

substituiu - execrando-a - a de legitimidade, opera a exclusão do âmbito dos debates jurídicos a respeito desta última. A legalidade é mito - cujo rito é o procedimento legal - e, assim, retém o estudioso do direito em um universo de dever-ser axiologicamente neutralizado. No discurso jurídico, esvazia o real e pacifica a consciência dos juristas, inclusive dos juízes, fazendo com que todos se conformem com a situação que lhes foi imposta por quem detém o poder de por o direito (Warat, 1979:129)".

32 "A legalidade formal, redutora do comportamento estatal administrativo ao quanto posto como norma pela entidade política, e, principalmente, a aceitação da suficiência dessa legalidade para a formação, informação e conformação do desempenho administrativo público, faziam com que, nos regimes antidemocráticos, a Administração Pública fosse cúmplice dos governantes de ocasião e o aparato burocrático administrativo fosse utilizado, sem embaraços, pelos autores de leis positivadas à força de baionetas" (Rocha, 2004:105).

${ }^{33}$ Cf. Davi, 2002:139-154. 
Observe-se que a ausência de subordinação entre as atividades estatais - legislativa, jurisdicional e administrativa - não deixa dúvida quanto ao dever de a administração pública se insurgir quanto a um ato legislativo inválido, mesmo que isto ainda não tenha sido pronunciado pelo Judiciário. A isonomia entre essas atividades e a sujeição única à Constituição dispensam a qualquer uma delas autonomia para se pautar de acordo com o que é legítimo à luz dos valores constitucionais supremos. ${ }^{34}$

\section{Dimensão constitucional do interesse público como fundamento do direito administrativo}

O conceito de interesse público deveria ocupar a preocupação central da doutrina do direito administrativo por sua relevância. Reserva-se a esse conceito indeterminado, ou determinável, toda a finalidade justificadora do exercício das competências públicas, o que traz como fundamental consequência a instrumentalização de todos dos poderes "titularizados" pelo Estado.

Tem-se imputado ao interesse público, principalmente a sua superioridade em relação aos interesses privados, todos os atos e procedimentos adotados pela administração pública que trazem algum traço de arbitrariedade ou uso abusivo de prerrogativas. Tal prática somente é facilitada pela ausência de transparência em torno desse conceito, que passa a ser um conveniente biombo para práticas incompatíveis com a ordem constitucional democrática. ${ }^{35}$

Admitimos que, por se tratar de um "suposto conceito jurídico indetermina$\mathrm{do}^{\prime \prime},{ }^{36}$ a noção de interesse público é temporal, mutável com o desenvolvimento das coisas e capaz de sofrer alterações diante da situação concreta, razão pela qual

\footnotetext{
${ }^{34}$ As razões fundamentais que autorizam e exigem essa atuação administrativa são, em síntese, as seguintes, conforme ensinamento de Gustavo Binenbojm (2006:175): a vinculação da administração à Constituição faz com que a ela também caiba zelar por sua supremacia; o chefe da administração tem o dever de ordenar o não cumprimento de lei inconstitucional para preservar a superioridade hierárquica da Lei Maior; não é monopólio do STF, a quem cabe a última palavra, a interpretação e aplicação das normas constitucionais; a legitimação ativa para a propositura das ADIns restritas a algumas autoridades públicas dispensaria um tratamento desigual injustificável para as diversas administrações públicas do país; e, por fim, a disciplina da ação declaratória de constitucionalidade, ao aludir ao Poder Executivo como destinatário da decisão, tornou clara a possibilidade de descumprimento da lei pelos órgãos administrativos.

35 “Toda obra de Direito Administrativo alude a interesse público, mas sem definir a expressão nem apresentar um conceito mais preciso. O discurso restringe-se a afirmar a relevância do interesse público para a construção dos institutos do Direito Administrativo. Bem por isso, Tércio Sampaio Ferraz Júnior observou que o interesse público é um lugar comum e que, justamente por isso, dispensa definição precisa, o que permite utilização mais eficiente" (Justen Filho, 1999:115-136).

${ }^{36}$ A utilização pela doutrina brasileira da denominação "conceito jurídico indeterminado" é objeto de crítica por Eros Grau (2003:34) e será desenvolvido em seção específica sobre o tema.
} 
se torna complexa sua definição. Contudo, vale lembrar que a indeterminação não é um defeito, uma imperfeição prejudicial à aplicação do direito, mas sim, conforme Marçal Justen Filho (1999:118), um atributo destinado a permitir sua aplicação de forma mais adequada.

Partindo do posicionamento defendido por Celso Antônio Bandeira de Mello (2005:68-78), faremos uma breve síntese de como a doutrina nacional vem definindo o interesse público. Para esse autor, o interesse público não está divorciado do interesse das partes, manifestando-se como um conjunto de interesses dos indivíduos em sua qualidade de membros da sociedade. Afirma o jurista que essa conceituação tem o objetivo de desfazer dois mitos perigosos: primeiro, desmascarar a falsa noção de que o interesse público não pode ser defendido por particulares, mesmo quando seu desatendimento produz agravos pessoais; segundo, mitigar a suposição reinante entre nós de que todos os interesses "titularizados" pelo Estado seriam considerados interesses públicos. Sobre o tema, Hely Lopes Meirelles (2007:86) defende que os fins da administração consubstanciam-se na defesa do interesse público, “(...) assim entendidas aquelas aspirações ou vantagens licitamente almejadas por toda a comunidade administrada ou por uma parte expressiva de seus membros".

Para Maria Sylvia Zanella Di Pietro (2003:70-71), o interesse público é um princípio positivado na Lei oำ 9.784/99, art. 2º, cujo caráter de irrenunciabilidade obriga ao exercício das competências atribuídas à administração para sua consecução. Em relação ao conteúdo desse interesse público, a autora associa a ele o princípio da impessoalidade, asseverando que a administração pública não pode agir com vistas a beneficiar ou prejudicar pessoas determinadas, devendo nortearse sempre pelo interesse público.

Sobre o tema, Lúcia Valle Figueiredo (2004:33-34) admite que o conceito de interesse público é pragmático e, portanto, passível de conotações diversas, dependendo da época, da situação socioeconômica, das metas a atingir e de várias outras circunstâncias. Contudo, para a autora, essa indeterminação tem limites, o que chama de "núcleo mínimo de compreensão", que deverão ser retirados das normas e princípios informadores do ordenamento.

Para Odete Medauar (2006:130), o interesse público é um princípio do direito público em geral que rege muitos institutos e normas do direito administrativo. A expressão associa-se a bem de toda a coletividade e à percepção geral da vida na sociedade.

Apontando uma insuficiência doutrinária na precisão do termo "interesse público", Marçal Justen Filho (2005a:35-47), mesmo ciente das dificuldades que giram em torno de se definir uma noção passível de alterações históricas, políticas e sociais, adota uma conceituação negativa, partindo das seguintes exclusões: 
interesse público não é o mesmo que interesse do Estado. Nesse tópico, o autor inverte um raciocínio frequentemente disseminado na nossa doutrina, ao defender que o interesse é atribuído ao Estado por ser público e não o contrário. Assim, por opção política, existem alguns interesses públicos que não são atribuídos ao Estado, o que não implica que ao Estado seja lícito titularizar interesses de natureza privada, o que infringiria nosso princípio republicano; ${ }^{37}$

interesse público não se confunde com o interesse do aparato administrativo. Admite o autor que o Estado pode até defender certas conveniências, como sujeito de direito, assemelhando-se a um sujeito privado, mas essas vantagens não serão jamais reconhecidas como interesse público. Ele rejeita a distinção feita por Alessi (1970) entre interesse público primário e interesse público secundário, sob o argumento de que as conveniências egoísticas da administração pública não podem se consideradas nem como interesse - na acepção jurídica do termo - , nem como público, consistindo em meras conveniências circunstanciais alheias ao direito. Não é lícito ao Estado, em hipótese alguma, tentar obter a maior vantagem possível ao custo do sacrifício de direitos fundamentais;

interesse público não se confunde com interesse do agente público. Nesse item, o autor separa o interesse público do interesse privado do sujeito que exerce a função administrativa. A condição de agente público não altera o regime jurídico a que está submetido o agente público, seus bens e interesses pessoais;

interesse público não é o mesmo que interesse da totalidade, nem da maioria da população. Nesse sentido, não haveria uma diferença qualitativa entre o interesse público e o interesse privado, residindo a distinção apenas em um aspecto quantitativo. Tal solução não poderia ser aceita por dois motivos: primeiro, porque a unanimidade nunca seria alcançada; e, segundo, o critério da maioria conduziria à opressão, haja vista que o interesse público a ser respeitado numa democracia não é apenas o da maioria da população, mas também o da minoria, segundo parâmetros constitucionais. Existe interesse público em tutelar as

\footnotetext{
${ }^{37}$ Embora defenda esse posicionamento, o autor faz a seguinte ressalva: "Mas não há como eliminar a possibilidade prática de o Estado ser investido da titularidade de interesses privados. Tal ocorreu na história recentemente do Brasil. Por exemplo, quando, durante o período não democrático, houve confisco de bens privados, que foram integrados ao patrimônio da União. O Estado passou a ser titular de empresas que não envolviam qualquer espécie de interesse público, mantendo-as em seu poder e dando continuidade à atividade empresarial (...) A única solução jurídica em situações dessa ordem reside em o Estado imediatamente promover a reintegração dos bens e direitos privados a órbita apropriada. Verificando que se tornou, circunstancialmente, titular de interesse de natureza privada, o Estado não tem outra alternativa. O Estado deverá transferir os bens para a esfera dos particulares, gratuita ou onerosamente. Será teratológico e infringente à ordem constitucional que o Estado dê seguimento, por si mesmo, à realização dos interesses privados. Mais monstruoso seria atribuir o cunho de interesse público a atividades puramente privadas" (Justen Filho, 2005a:37).
} 
minorias raciais, mesmo que seus interesses eventualmente conflitem com os da maioria do povo. Do mesmo modo não é porque a maioria do povo brasileiro gosta de futebol que os assuntos relacionados a esse esporte devam ser regidos pelo direito público;

interesse público não é o mesmo que interesse da sociedade. Não é admissível numa democracia que o todo - sociedade - seja considerado como algo superior à soma dos interesses individuais. A desvinculação entre o individual e o público gera o reconhecimento de interesses supraindividuais, expressão do autoritarismo, próprio das políticas totalitárias.

Afastadas essas possibilidades, ainda assim não se tem uma definição de interesse público, o que leva o autor a crer na existência de um "atributo peculiar" que qualifique de público algum interesse. Essa reflexão remete-nos para a diferença entre o público e o privado, o que induz ao reconhecimento da indisponibilidade como característica comum a tudo aquilo que é colocado sob o severo regime de direito público. Não podendo ser objeto de transigência, o interesse sai da esfera privada e passa a integrar a esfera pública. Assim, concluímos que o atributo peculiar é a indisponibilidade. O interesse é público por ser indisponível e não o inverso, “(...) portanto a indisponibilidade não é consequência da natureza pública do interesse, pelo contrário, o interesse é reconhecido como público por ser indisponível, porque não pode ser colocado em risco, porque sua natureza exige que seja realizado" (Justen Filho, 2005a:43).

Diante de tal afirmação, acrescenta Celso $\operatorname{Castro~}^{38}$ que a indisponibilidade também é uma característica, um atributo do interesse, não se constituindo em essência, mas sim em consequência do valor transcendental de algo que extrapola a esfera do individual, do imanente, e por isso torna-se indisponível. Sintetizando o pensamento do autor, a indisponibilidade não justifica o interesse público, apenas o identifica. A sua justificativa encontra-se no seu valor transcendental.

Em razão disso, entendemos que a diferença entre interesse público e interesse privado não reside numa questão técnica, quantitativa, aritmética, mas sim numa questão ética, qualitativa, relacionada aos valores e princípios que a administração deverá realizar, o que resulta no único posicionamento acertado diante de tudo o que vimos sobre interesse público: “[o] núcleo do direito administrativo não reside no interesse público, mas sim nos direitos fundamentais" (Castro, 1995:44).

Conforme preceitua Agostín Gordillo (2003:II-7), nenhum interesse público "entendido como abstração permanente e generalizado" pode ser aceito axiomá-

\footnotetext{
${ }^{38}$ Aula do Curso de Especialização em Direito do Estado. Fundação Faculdade de Direito. Pavilhão de aulas do Canela, Salvador, 23 nov. 2006.
} 
tica ou dogmaticamente. Terão que ser identificados os interesses em jogo, para que se possa avaliar em cada caso a intervenção ou abstenção administrativa mais adequada. Além disso, o interesse público invocado previamente à aplicação do direito ou anterior à atividade decisória da administração pública não poderá legitimar a atuação estatal, pois “(...) somente uma decisão proferida por meio de procedimento satisfatório e com respeito aos direitos fundamentais poderá traduzir o interesse público", ${ }^{39}$

Temos, portanto, que o interesse público não é o fundamento da atividade administrativa, mas sim seu resultado, razão pela qual a preocupação central da doutrina não deverá recair no interesse público, inicialmente, mas sim no respeito ao procedimento que deverá ter como principal objetivo a garantia dos direitos fundamentais com ênfase na dignidade humana.

\section{Dimensão constitucional da discricionariedade e do mérito administrativo}

Inicialmente, vale fazer um breve relato da aferição histórica da discricionariedade. No século XVI, ela era considerada a genuína expressão da soberania do monarca, até a Revolução Francesa, quando surgiu a preocupação com os direitos individuais. A partir do século XIX houve a retirada da prerrogativa do Executivo de editar leis, substituindo-se a vontade do monarca pela vontade do povo. Surgiu a separação dos poderes e a distinção entre governo e administração, sendo ao primeiro atribuída a função política e a função discricionária livre da apreciação judicial, e à segunda a administração propriamente dita.

Ensina Andreas J. Krell (2004:19-25) que o grande desafio para o jovem Estado de direito era conciliar a tradicional liberdade decisória do executivo com a legalidade. Nesse tempo, a discricionariedade era vista como uma herança indesejável do absolutismo e deveria ser estirpada. Em momento posterior, porém, foi visto que a discricionariedade era necessária para a eficiência da administração, pois ao legislador não é possível prever todos os acontecimentos; por isso, deixa à discrição do administrador.

Percebemos do exposto sobre a discricionariedade que ela originou-se do poder ilimitado da monarquia absoluta, para depois se transformar em uma técnica de eficiência para a administração, o que nos leva a duvidar dessa finalidade vir-

\footnotetext{
${ }^{39}$ Justen Filho, 2005a:45. Para o jurista: “O processo de democratização conduz a necessidade de verificar em cada oportunidade, como se configura o interesse público. Sempre e em todos os casos, tal se dá por meio da intangibilidade dos valores relacionados aos direitos fundamentais".
} 
tuosa como única intenção do poder político em admiti-la - maior eficiência para a administração - para apostarmos numa finalidade concorrente bem menos desejada: a abertura para o arbítrio.

Superada essa visão positivista da legalidade com vinculação única do administrador, passamos a considerar a administração vinculada ao sistema jurídico globalmente considerado, inserindo-se nele além das normas-regras, as normasprincípios e a Constituição, o que reduz em muito o espaço de liberdade outorgado pelo legislador à administração. Assim, esta última terá que guiar também sua escolha de acordo com os princípios constitucionais. Portanto, o cerne da questão, a espinha dorsal da problemática envolvendo a discricionariedade administrativa e o controle judicial possível de ser realizado, é a delimitação do mérito administrativo. Doutrinadores e Judiciário ainda divergem sobre os limites do mérito administrativo e, principalmente, sobre a extensão do controle judicial que poderá incidir sobre a prática discricionária. Nesse ponto, cabe rever, sem pretensa exaustividade, parte da literatura existente sobre a matéria, para que possamos avaliar criticamente a situação atual.

Odete Medauar (2006:111-114) define o mérito administrativo como expressão do juízo de conveniência e oportunidade efetuadas pela autoridade à qual se conferiu o poder discricionário da escolha. Para ela, a discricionariedade pressupõe uma "liberdade-vínculo", o que demonstra uma real preocupação em limitar a liberdade política dos agentes públicos imbuídos do agir discricionário. Acrescenta que “(...) o processo eleitoral ou a nomeação para um cargo de confiança na cúpula do Executivo não ensejam passaporte para o absoluto, que dotaria os administradores de poderes incondicionados" (Medauar, 2006:114).

Lúcia Valle Figueiredo (2004:213) critica o que hoje tem sido admitido como mérito do ato administrativo, um "abre-te sésamo" a legitimar desmandos administrativos insuscetíveis de controle, uma vez que é corriqueiro o Judiciário furtarse ao controle de determinados atos por temer adentrar no mérito, deixando de aferir os próprios postulados da legalidade.

Celso Antônio Bandeira de Mello (2003:48-82) define o mérito administrativo como o círculo de liberdade indispensável para avaliar, perante o caso concreto, o que é conveniente e oportuno. A discricionariedade é por ele definida como "liberdade remanescente" para eleger, razoavelmente, um, entre pelo menos dois comportamentos cabíveis perante o caso concreto, quando, por força da liberdade conferida no mandamento, dela não se possa extrair objetivamente uma decisão unívoca.

Hely Lopes Meirelles (2007:155) acredita ser o mérito administrativo a valoração dos motivos e a escolha do objeto do ato, o que ocorre somente quando a administração estiver autorizada a decidir sobre oportunidade, conveniência e justiça da decisão a ser tomada, o que só ocorre nos atos administrativos discricionários. 
Para Maria Sylvia Zanella Di Pietro (2001:129-130), a despeito de todos os entendimentos equivocados sobre o tema, não se pode deixar de admitir que ao Judiciário é vedado controlar o mérito do ato administrativo, que considera como o aspecto político que abrange a oportunidade e a conveniência. Não obstante, ressalva como inaceitável utilizar-se do mérito como escudo da atuação judicial em casos que envolvam questões de legalidade e moralidade administrativa, o que somente poderá ser evitado com a delimitação exata do que é discricionariedade. Esse termo é definido pela autora como a possibilidade de escolha entre duas ou mais soluções igualmente válidas, segundo critérios de conveniência, oportunidade, justiça e equidade, ou seja, segundo razões de mérito.

Caio Tácito (1993:25-42) entende que o mérito do ato administrativo não pode ser mais do que o círculo de liberdade indispensável para avaliar, no caso concreto, o que é conveniente e oportuno para o objetivo da lei. Nunca será liberdade para agir em dissonância com este objetivo.

Seabra Fagundes (1950:174-180) defende que o mérito administrativo compreende questões relativas a interesses, não se envolvendo em questões de direitos. Assim, não cabe ao Judiciário resguardar interesses contrariados pelo ato administrativo, mas apenas desrespeito aos direitos individuais acidentalmente sofridos. Para o autor, o mérito constitui-se de elementos políticos e estritamente técnicos, peculiares à administração. Por essa razão é obra exclusiva do Executivo, não podendo o Judiciário nele penetrar sem ferir a separação e independência de poderes.

Observamos, em todas as definições colacionadas, que não existe univocidade de pensamento entre os doutrinadores, mas evidencia-se uma tendência atual pela sindicabilidade do que se denomina "mérito administrativo", que está sendo visto como uma liberdade mitigada para a atuação da administração.

Marçal Justen Filho (2005a:154-167) tem um posicionamento sobre a discricionariedade que difere dos já apresentados. Para esse autor, a discricionariedade não consiste em uma simples escolha entre as várias possíveis. Quando a lei configura uma discricionariedade, pode agir assim pela impossibilidade de solucionar antecipada e abstratamente todas as alternativas de solução de um problema, ou então pode fazê-lo por julgar que a matéria exige conhecimento técnico-científico, variando as soluções de acordo com o progresso.

Por meio de uma perspectiva neoconstitucional, Gustavo Binenbojm (2006:38) expõe sua versão da discricionariedade administrativa, afastando a ideia de legalidade, conceito em crise, para substituí-la pela juridicidade administrativa. Essa modificação altera muito o tratamento dispensado ao tema, haja vista que a vinculação direta da administração à Constituição não mais permite a velha dicotomia entre vinculação e discricionariedade, mas sim uma gradação maior ou menor de vinculação dos atos administrativos à juridicidade, que representa a lei, os princí- 
pios e a Constituição. O que significa dizer que o maior ou menor grau de vinculação do administrador à juridicidade corresponderá ao maior ou menor grau de "controlabilidade" judicial de seus atos.

No mesmo sentido, Juarez Freitas (2007:13-14) considera legítima a discricionariedade apenas quando seu exercício está conforme com as regras e, acima delas, com os exigentes princípios constitucionais, que precisam ter sua primazia impregnada na mente dos controladores e administradores como empreendimento cultural premente. Para o autor, é necessária uma nova disciplina capaz de desfazer os autoenganos sobre a discricionariedade, o que será um trabalho de cunho muito mais pedagógico do que de redefinição técnica.

Ocorre, dessa forma, o estreitamento do denominado mérito administrativo, que fica muito mais permeável ao controle judicial, já que a aplicação dos princípios em nada implica liberdade para o agir subjetivo, devendo o Judiciário verificar, no caso concreto, se o agente público investido da competência discricionária desconsiderou os princípios aplicáveis à situação, que poderiam, inclusive, ter reduzido a discricionariedade a zero. ${ }^{40}$

\section{Conclusão}

Depreendemos do que foi exposto que o direito administrativo precisa do constitucionalismo para superar sua defasagem teórica, o que ocorrerá com a adoção do sistema de direitos fundamentais e do sistema democrático. Esses vetores serão responsáveis por imprimir mudanças radicais na relação entre a administração e os cidadãos - aproximando-os e informando-os - afastando o paradigma weberiano de distanciamento da administração dos conflitos sociais e políticos como forma de garantir sua autonomia e eficiência. ${ }^{41}$

Defendemos o estabelecimento de um canal de comunicação entre a política e o direito, nos moldes propostos por Maria Paula Dallari Bucci (2006a:38-40), o que alimentará as alternativas facultadas ao administrador público no exercício da com-

\footnotetext{
40 “Essa hipótese de eliminação da discricionariedade ocorre quando as alternativas postas na lei como conformes ao direito e, portanto, passíveis de serem escolhidas pelo administrador mostrarem-se, em um determinado caso, vedadas por incidência de um princípio, o que reduzirá suas opções a apenas uma alternativa" (Binenbojm, 2006:230-231).

41 "Para nós, a participação serve justamente para romper com o distanciamento entre sociedade e Administração, aproximando-a dos conflitos sociais e políticos e proporcionando aos administrados uma gestão responsiva, dinâmica, atenta à pluralidade dos interesses sociais, com vistas voltadas à efetivação dos direitos fundamentais, fator essencial para a eficiência das atividades de bem-estar que devem ser conduzidas pela Administração e para a sua legitimidade, tanto em função da adesão racional da sociedade a um conjunto de medidas concretas, políticas ou programas que esta ajudou a formular, decidir e muitas vezes a executar, como em razão da eficiência dessa atuação conjunta" (Perez, 2006:169).
} 
petência discricionária. Esse abandono do isolamento político pela administração resultará na definição do conteúdo de interesse público de forma participativa, em que os titulares do referido interesse serão consultados.

Essa transformação deverá ser instrumentalizada pelo direito administrativo, que passará a reger não somente atos administrativos como expressão da simples execução da lei, mas toda a atividade administrativa, desde a escolha política do caminho a ser seguido, passando por sua execução, até o alcance dos fins. Assim, teremos o mais eficaz instrumento para a concretização dos valores constitucionais, um direito administrativo constitucionalizado, capaz de resolver os problemas entre Estado e cidadão, autoridade e liberdade, sociedade e indivíduo. Ressaltamos que não se trata de um campo estritamente jurídico, mas sim jurídico-político.

Existe uma lacuna no espaço intraestatal entre o momento da decisão e o instante da execução. Essa lacuna é um vácuo, no qual as leis e normas não conseguem manter seu poder coativo. Falta o instrumento correto: para nós, a atuação do direito administrativo.

\section{Referências}

ALESSI, Renato. Instituciones de derecho administrativo. Barcelona: Bosch, 1970. t. I. Apud JUSTEN FILHO, Marçal. Curso de direito administrativo. São Paulo: Saraiva, 2005.

BANDEIRA DE MELLO, Oswaldo Aranha. Princípios gerais de direito administrativo. 3. ed. São Paulo: Malheiros, 2007. v. I.

BAPTISTA, Patrícia. Transformações do direito administrativo. Rio de Janeiro: Renovar, 2003.

BARCELLOS, Ana Paula de. A eficácia jurídica dos princípios constitucionais. 2. tiragem. Rio de Janeiro: Renovar, 2002.

- Neoconstitucionalismo, direitos fundamentais e controle das políticas públicas. Revista de Direito Administrativo, São Paulo, n. 240, 2005.

BARROSO, Luís Roberto. Interpretação e aplicação da Constituição. 5. ed. São Paulo: Saraiva, 2003a.

. Fundamentos teóricos e filosóficos do novo direito constitucional brasileiro:

pós-modernidade, teoria crítica e pós-positivismo. In: ANJOS FILHO, Robério Nunes dos (Coord.). Estudos de direito constitucional. Salvador: Podium, 2003b.

BINENBOJM, Gustavo. Uma teoria do direito administrativo. Rio de Janeiro: Renovar, 2006. 
BUCCI, Maria Paula Dallari. Direito administrativo e políticas públicas. 2. tiragem. São Paulo: Saraiva, 2006a.

CANOTILHO, J. J. Gomes. Direito constitucional. Coimbra: Almedina, 1995.

. Direito constitucional e teoria da Constituição. 7. ed. Coimbra: Almedina, 2003.

CASTRO, Celso Braga de. Desvio de conduta na administração pública. 1995. 135 f. Dissertação (Mestrado em Direito) - Faculdade de Direito, Universidade Federal da Bahia, 1995.

CLÈVE, Clèmerson Merlin. Temas de direito constitucional. São Paulo: Acadêmica, 1993.

COMPARATO, Fábio Konder. Ensaio sobre juízo de constitucionalidade das políticas públicas. In: MELLO, Celso Antônio Bandeira de (Org.). Estudos em homenagem a Geraldo de Ataliba. São Paulo: Malheiros, 1997. v. 2.

. Planejar o desenvolvimento: a perspectiva institucional. In: BERNARDO, Antonio C. et al. Brasil, o desenvolvimento ameaçado: perspectivas e soluções. São Paulo: Unesp, 1989.

DAVI, Kaline Ferreira. O direito administrativo, os atos de governo e os direitos sociais: uma análise a partir do neoconstitucionalismo. Revista de Direito Constitucional e Internacional, São Paulo, n. 62, 2007.

DI PIETRO, Maria Sylvia Zanella. Discricionariedade administrativa na Constituição de 1988. 2. ed. São Paulo: Atlas, 2001.

Direito administrativo. 15. ed. São Paulo: Atlas, 2003.

DWORKIN, Ronald. Levando os direitos a sério. São Paulo: Martins Fontes, 2002.

ESCOLA, Héctor Jorge. El interes público como fundamento del derecho administrativo. Buenos Aires: Depalma, 1989.

FAGUNDES, M. Seabra. O controle dos atos administrativos pelo Judiciário. 2. ed. Rio de Janeiro: José Konfino, 1950. Apud MEIRELLES, Hely Lopes. Direito administrativo brasileiro. 33. ed. São Paulo: Malheiros, 2007.

FERRAZ, Tércio Sampaio. Constituição de 1988. São Paulo: Atlas, 1989.

FERREIRA FILHO, Manoel Gonçalves. Aspectos do direito constitucional contemporâneo. São Paulo: Saraiva, 2003.

FIGUEIREDO, Lúcia Valle. O devido processo legal e a responsabilidade do Estado por dano decorrente do planejamento. Revista Trimestral de Direito Público, São Paulo, n. 11, 1995. 
. Curso de direito administrativo. 7. ed. São Paulo: Malheiros, 2004.

FREITAS, Juarez. Discricionariedade administrativa e o direito fundamental à boa administração pública. São Paulo: Malheiros, 2007.

GARCIA, Maria. Prefácio. In: BUCCI, Maria Paula Dallari. Direito administrativo e políticas públicas. 2. tiragem. São Paulo: Saraiva, 2006.

GARCÍA DE ENTERRÍA, Eduardo. La lucha contra las imunidades del poder en el derecho administrativo. Revista de Administracion Publica, Madrid, n. 38, mayo/ago. 1962.

; FERNÁNDEZ, Tomás-Ramón. Curso de derecho administrativo. São Paulo: Revista dos Tribunais, 1990. 2 v.

GORDILLO, Agostín. Tratado de derecho administrativo. 8. ed. Buenos Aires: Fundación de Derecho Administrativo, 2003. t. 1 e 2.

GRAU, Eros Roberto. A ordem econômica na Constituição de 1988. 7. ed. São Paulo: Malheiros, 2002.

. Direito posto e direito pressuposto. 5. ed. São Paulo: Malheiros, 2003.

HABERMAS, Jürgen. Direito e democracia entre facticidade e validade. 2. ed. Rio de Janeiro: Tempo Brasileiro, 2003. 2 v.

. A inclusão do outro. 12. ed. São Paulo: Loyola, 2004.

HESSE, Konrad. A força normativa da Constituição. Trad. Gilmar Ferreira Mendes. Porto Alegre: Sergio Antonio Fabris, 1991.

JUSTEN FILHO, Marçal. Conceito de interesse público e a personalização do direito adminsitrativo. Revista Trimestral de Direito Público, São Paulo, n. 26, 1999.

. Curso de direito administrativo. São Paulo: Saraiva, 2005a.

. O direito administrativo reescrito: problemas do passado e temais atuais. Revista Negócios Públicos, Curitiba, ano II, n. 6, 2005b.

MEDAUAR, Odete. Direito administrativo moderno. 10. ed. São Paulo: Revista dos Tribunais, 2006.

MEIRELLES, Hely Lopes. Direito administrativo brasileiro. 33. ed. São Paulo: Malheiros, 2007.

MELLO, Celso Antônio Bandeira de (Org.). Estudos em homenagem a Geraldo de Ataliba. São Paulo: Malheiros, 1997. v. 2.

. Curso de direito administrativo. 20. ed. São Paulo: Malheiros, 2005. 
MORAES, Germana de Oliveira. Controle jurisdicional da administração pública. 2. ed. São Paulo: Dialética, 2004.

MOREIRA NETO, Diogo de Figueiredo. Mutações do direito público. Rio de Janeiro: Renovar, 2006.

MÜLLER, Friederich. Quem é o povo? A questão fundamental da democracia. 3. ed. São Paulo: Max Limonad, 2003.

OTERO, Paulo. Legalidade e administração pública: o sentido da vinculação administrativa a juridicidade. Coimbra: Almedina, 2007.

RIVERO, Jean. Direito administrativo. Coimbra: Almedina, 1981. Apud MEIRELLES, Hely Lopes. Direito administrativo brasileiro. 33. ed. São Paulo: Malheiros, 2007.

ROCHA, Cármen Lúcia Antunes. Princípios constitucionais da administração pública. Belo Horizonte: Del Rey, 2004.

SANTOS, Boaventura de Souza. Pela mão de Alice: o social e o político na pós-modernidade. 11. ed. São Paulo: Cortez, 2006.

SARMENTO, Daniel. Direitos fundamentais e relações privadas. 2. ed. São Paulo: Lumen Juris, 2006.

SCHIER, Paulo Ricardo. Filtragem constitucional. Porto Alegre: Sérgio Antonio Fabris, 1999.

. Ensaio sobre a supremacia do interesse público sobre o privado e o regime jurídico dos direitos fundamentais. In: SARMENTO, Daniel (Org.). Interesses públicos versus interesses privados: desconstruindo o princípio da supremacia do interesse público. Rio de Janeiro: Lumen Juris, 2005.

SCHMIDT-ASSMANN, Eberhard. La teoria general del derecho administrativo como sistema. Madrid: Instituto Nacional de Administração Pública, 1980. 